\title{
Organised Crime in Italy: Mafia and Illegal Markets - Exception and Normality
}

\author{
Letizia Paoli
}

\section{Introduction}

In Europe and elsewhere, southern Italian mafia organisations have long been considered a paradigm of organised crime or tout court identified with it. In the core sections of this article (4 and 5), the specificities of the southern Italian mafia phenomenon are singled out and the other protagonists of organised crime active in the country are briefly described. (The comparative synthesis at the end of this Part will show that the Italian mafia is an inadequate paradigm for what is today understood as organised crime in Europe.) Before analysing Italian mafia organisations and other criminal groups, the second and third sections of the article briefly reconstruct the Italian discourse on organised crime and review official sources of information.

Following the two bulk sections on the main manifestations of organised crime in Italy, the sixth section briefly presents some estimates and the key protagonists of Italy's illegal markets, showing their normality vis-à-vis other illegal markets in Europe. The seventh and eighth sections single out two further specificities of Italian mafia organisations: namely, their extensive infiltration of the legitimate economy and the political sphere. Some concluding remarks follow.

\section{The Public and Scientific Discourse about the Mafia: Four Key Concepts}

To a larger extent than in any other European country, organised crime has been a relevant topic of the public and scientific discourse in Italy since the mid-nineteenth century. True, the expression 'criminalità organizzata' (organised crime) became common only in the last 40 years of the twentieth century and is still nowhere precisely defined in the Italian legislation. Since the unification of the country in 1861, however, the government crime policies have been based on the assumption of the existence of stable criminal organisations in southern Italy and, particularly, in Sicily. Since then the criminal groups of the latter region, collectively labelled as mafia, have been most intensively focused on by the Italian media, public opinion and government authorities and have been considered an ideal-type of delinquent 
association and, later on, of organised crime itself (see Paoli, 1997: ch. 1, [2000] 2003b).

The association of the mafia with organised crime has not gone unchallenged. At least three main other conceptualisations of the mafia have been proposed and have at different times dominated public or scientific debate. These three other understandings of mafia can be referred to with the keywords of 'secret society', 'individual attitude and behaviour' and 'enterprise' and will be synthetically reviewed here together with the fourth identifying mafia with a criminal organisation.

\subsection{Secret Society}

The idea that Sicily was home to a well organised and powerful secret society called 'Mafia' began to be circulated by the media right after country unification in 1861 (see Fulvetti's report in Part I). This conceptualisation found great impulse in the publication - first in 1908-09 in instalments on a Palermitan newspaper and successively as a book - of the novel I Beati Paoli, which was written by Luigi Natoli under the pseudonym of William Galt (Natoli, [1908-09] 1993). The plot, which drew from rich folk material, was about a secret sect - the Beati Paoli - active in the early eighteenth century, which administered justice in a situation of weakness and corruption of public authorities, a sort of collective Robin Hood that opposed short-sighted legalistic conceptions and avenged the sufferings of oppressed people (Eco, [1971] 1993). Natoli's novel obtained enormous success and was read by all social classes from the aristocracy to the landless peasants (La Duca, [1971] 1993). In Sicily the Beati Paoli came to be seen - both in the popular imagination and in the ideology of mafia groups - as a proto-manifestation of the mafia.

In other re-elaborations of this image, the mafia was likewise presented as an almighty, invincible, secret society but its legitimacy was either questioned or denied. The spread of this view was primarily the result of the activities of 'moral entrepreneurs', who published newspaper articles and romanticised reports on the mafia. From the late nineteenth century, the latter heedlessly mixed popular legends and ethnic stereotypes with information drawn from mafia criminal cases, their only aim being the satisfaction of public curiosity on such an intriguing theme. In the 1890s and again in the fascist era, for example, the Giornale di Sicilia regularly held a column on mafia criminal proceedings. Popular criminal cases were also summarised and simplified in serialised novels. For the Amoroso case, one of the most important proceedings held at the end of the nineteenth century, the Giornale di Sicilia also published the official court hearings in special issues (Hess, [1970] 1973: 96-7). Moreover, the events disclosed in that case were re-elaborated in a thrilling and sentimental novel published under the title of La Cavalleria di Porta Montalto o La Mafia Siciliana (The Cavalry of Porta Montalto or the Sicilian Mafia; Scalici, 1885). 


\subsection{Criminal Association}

The view of the mafia as a powerful secret society was occasionally exploited by law enforcement agencies to give empirical content to the official definition of mafia. In the official discourse of the late nineteenth century and early twentieth century, in fact, this was mostly identified with the associational offences defined by the Italian penal code, thus losing its geographical and social peculiarities. During the rule of the so-called 'Historical Right' (1860-76), for example, the term 'mafia' was virtually used as a synonym of associazione di malfattori (that is, association of evildoers), which was the offence inherited from the Piedmontese Penal Code and allowed for summary imprisonment. Depending on the political influences at work and the priorities of public order, the label of mafia could thus be applied to very different social manifestations, ranging from movements of political opposition to peasant revolts, from union unrest to terrorist groups (Pezzino, 1987: $913 \mathrm{ff}$.; Brancato, [1972] 1986: 128-30).

The understanding of the mafia as a criminal association exempt of any cultural legitimacy became once again dominant during the fascist regime. As Cesare Mori, the 'Iron Prefect' in charge of mafia repression in the 1920s, wrote, 'whatever form it takes and however it acts, the mafia, by its very nature, constitutes [...] the typical configuration (la figura tipica) of the criminal association' ([1932] 1993: 32). This concept was officially stated in the 1930 Fascist Penal Code. This defined anew the offence of associazione per delinquere (criminal association) that had been introduced by the first unitary Penal Code (Art. 248) in 1889. Rarely used in the liberal age, the offence of criminal association became a centre-pillar of the repression of the mafia carried out by the fascist regime. Given its indefiniteness and ductility, the new Article $416^{1}$ allowed law enforcement agencies to prosecute individuals not charged with specific crimes, but who could be arrested and convicted simply on the grounds of being mafiosi (Ingroia, 1993: 12-13). Criminal association, in fact, constituted a sort of permanent offence and suspects could be arrested and held as if they had been caught in the act (in flagrante) (see Mori, 1993: 314).

However, for the same reasons Article 416 was rarely or unsuccessfully applied after the restoration of the democratic regime in 1945. Since then courts and legal scholars maintained that the guilt of each defendant could no longer be automatically deduced from the conceptualisation of mafia as a criminal association but had to be proved in each single case. As a result of these higher standards, anti-mafia

1 In the first two paragraphs still valid nowadays, Article 416 states: 'When two or three people associate in order to commit several crimes, those that promote or establish or organise the association are punished, only for this, with imprisonment from three to seven years. For the mere membership of the association, the penalty is from one to five years'. 
investigations charging this provision usually ended up with the acquittal of most defendants for insufficiency of proof in later court verdicts (Turone, 1984: 3-31; Ingroia, 1993: 10-54).

In September 1982, under the pressure of a series of murders of high-ranking state officials in Sicily, Article 416bis was added to the Italian Penal Code. This can be seen as the culmination of a strand of discourse that has been fostered by large parts of the law enforcement community since Italy's unification: namely, the idea of the mafia as a criminal association. At the same time, however, by transforming a meta-juridical concept - that of mafia - into a juridical category, the new provision specified and restricted such a claim and defined with precision what was meant by associazione a delinquere di tipo mafioso. The new bill integrated proposals of the communist member of Parliament Pio La Torre, who had been murdered by Sicilian mafiosi in early 1982, and rulings of the Corte di Cassazione and is therefore usually called the La Torre Act. According to Article 416bis, a mafia-type delinquent association consists of three or more persons, and

\begin{abstract}
those who belong to it make use of the power of intimidation afforded by the associative bond and the state of subjugation and criminal silence (omertà) which derives from it to commit crimes, to acquire directly or indirectly the management or control of economic activities, concessions, authorisations or public contracts and services, either to gain unjust profits or advantages for themselves or for others, or to prevent or obstruct the free exercise of the vote, or to procure votes for themselves or for others at a time of electoral consultation. $^{2}$
\end{abstract}

The mafia was thus defined as a criminal organisation of a specific type and the applicability of the related penal provisions was restricted, putting an end to the tradition of elasticity and arbitrariness that had so long characterised anti-mafia law enforcement action. With its references to the concepts of mafia and omertà, in fact, Article 416 bis can hardly be exported outside the southern Italian context. However, the wording chosen by Italian law-makers is somewhat vaguer. The last paragraph of Article 416bis states: 'the dispositions of the present article apply also to the camorra and other criminal associations whatever their local name, pursuing aims similar to those of mafia-type delinquent associations by exploiting the power of intimidation afforded by the associative bond'.

2 The last clause concerning the exercise of vote was added in 1992, after the Mani Pulite (Clean Hands) investigations of the early 1990s had revealed extensive corruption networks including mafia members (Barbacetto, Gomez and Travaglio, 2002). 
Organised Crime in Italy

\subsection{Individual Attitude and Behaviour}

Since the late nineteenth century the association of the mafia with a criminal organisation was challenged by the 'Sicilianist' movement with a fair degree of success. This was a cultural and political movement that was promoted by Sicily's ruling strata and developed in order to oppose what was perceived as an indiscriminate criminalisation of all Sicilians by the Italian law enforcement apparatus and Italian public opinion as a whole (Marino, 1988; Pezzino, 1990). In the eyes of the sicilianisti, the mafia was merely an attitude, the product of a particularly fierce Sicilian reaction to the foreign powers, which had dominated the island for centuries (see Giuseppe Pitrè's famous definition of the mafia in Fulvetti's chapter on the history of organised crime in Italy in Part I).

The Sicilianist view of the mafia deeply influenced the social scientists carrying out the first field studies in Sicily between the 1960s and the early 1980s. For them the mafia was simply a sub-cultural attitude as well as a form of behaviour and power. That is, they asserted, there were mafiosi, single individuals, who embodied determined sub-cultural values and exercised specific functions within their communities, but no mafia organisation existed as such (Hess, 1973; Blok, [1974] 1988; Schneider and Schneider, 1976). Still in 1983, Pino Arlacchi's successful book, $L a$ mafia imprenditrice (Mafia Business), opened with the following statement: 'Social research into the question of the mafia has probably now reached the point where we can say that the mafia, as the term is commonly understood, does not exist' ([1983] 1988: 3, emphasis in the original; see also Catanzaro, [1991] 1992).

Whereas the strictly non-corporate view of the mafia held by this first generation of scholars looks today outdated, the systematic analysis of the social and economic conditions that favoured the development of the mafia - as Henner Hess calls it, 'the phylogenesis' of mafia power (1973: 43) - constitute the most durable part of their works. Later historical research has however proved that mafia methods were spread not only in the large estates of the Sicilian inland but also in the so-called 'golden valley' (Conca d'Oro) of fertile citrus groves surrounding Palermo, where ownership was scattered and intensive agriculture the norm (Lupo, 1993).

\subsection{Enterprise}

From the mid-1980s on, when judicial investigations started to provide clear and solid proof of the existence of well-structured mafia groups, attention shifted towards the entrepreneurial features of mafia actors. Contrasting the 'culturalist' view more or less openly, the mafia was conceptualised as an enterprise and its economic activities became the focus of academic analyses.

The new paradigm was established in the early 1980s by Arlacchi, who was the first scholar to talk about the 'entrepreneurial mafia', highlighting the mafiosi's growing involvement in licit and illicit economic activities (1988). As shown in 
the introduction to Part I, this economic conceptualisation of the mafia dominated the scientific debate until the early 1990s. Most scholars pursuing this approach, however, tended to deny Arlacchi's idea of 'entrepreneurial transformation' of mafia groups, usually ascribing a primarily economic-oriented behaviour even to traditional mafiosi and neglecting the impact of traditional imprinting on the behaviour of contemporary mafia entrepreneurs. Thus, in this latter work, traditional mafiosi have been identified tout court with the few figures who showed a clearly modern acquisitive attitude in the traditional economic and social system of western Sicily and southern Calabria and presented as the true expression of the local bourgeoisie. In their turn, contemporary mafia groups have been assimilated into the model of legal business firms (Catanzaro, 1992; Santino, 1988; Santino and La Fiura, 1990; Pezzino, 1993; 1987; 1988; Recupero, 1987; Lupo, 1988; 1993; Pizzorno, 1987; for the shortcomings of this interpretation, see the introduction to Part I).

A variant of the long dominant enterprise approach was proposed in the early 1990s by Diego Gambetta. According to him, the mafia must be seen as 'a specific economic enterprise, an industry which produces, promotes, and sells private protection' (1993: 1). By shifting attention away from traditional licit and illicit entrepreneurial activities, Gambetta's work points to one of the most important functions historically played by Sicilian and Calabrian mafia groups and paves the way for a reassessment of the political dimension of mafia associations. His interpretation was, however, criticised for his one-sided emphasis on protection, which can be justified only by a very selective reading of past and present sources (Nelken, 1995; Paoli, 2003b).

\subsection{Towards the Development of a New Paradigm?}

Drawing from Gambetta's contribution, more recent analyses have focused on the political dimension of mafia power (Santino, 1994; Paoli, 2003b; Santoro, 1998, 2000). Emphasised by mafia defectors, the cultural codes and symbols that constitute the canopy of mafia apparatus of legitimation, have also been investigated anew (Siebert, 1994; Di Lorenzo, 1996; Di Maria and Lavanco, 1995; Dino, 1998; Paoli, 2003b; see infra). Codes and symbols are however no longer seen as attributes of single individuals, as was the case in the first pioneering studies carried out by foreign scholars in the 1960s and 1970s, but as means employed by mafia groups to build their own collective identity and legitimise their power. This shift is due to the incorporation, with five to ten years of delay, of the findings of police and judicial investigations into scientific reflection on the mafia. Since the mid-1980s, in fact, these have proved beyond any reasonable doubt the existence of two large and structured mafia organisations in Sicily and Calabria - Cosa Nostra and the 'Ndrangheta - and a variety of more ephemeral mafia and pseudo-mafia groups in several parts of southern Italy. 


\section{The Official Sources of Information}

Since the late nineteenth century the Italian Parliament has set several ad hoc committees of inquiry to investigate the problems of public order and the mafia, first in Sicily and later on in the whole of southern Italy. The first commission of inquiry was established five years after Italy's unification, in 1866 (Pezzino, 1987). However, parliamentary interest in the mafia has by no means been constant. On the contrary, it usually rose when public unrest and sensational mafia murders attracted national attention to the mafia problem or when government agencies - on their own initiative or, more frequently, reacting to serious crimes - staged large repressive campaigns in Sicily and other regions of the Italian Mezzogiorno (literally Midday, a term used to refer to southern Italy).

\subsection{The Commissione Parlamentare Antimafia and Other Committees of Inquiry}

Reflecting the popularity of the different conceptualisations of the mafia sketched in the previous section, sudden turns have also characterised public and political discourse on the mafia in the decades following the end of the Second World War. Despite the precise reports made by some left-wing politicians, during the $1950 \mathrm{~s}$ and early 1960s national public opinion and even government and parliamentary bodies showed only a very limited awareness of the mafia phenomenon. The word 'mafia' hardly ever appeared in Italian newspapers, and a dismissive attitude was widespread among law enforcement officers (with very few exceptions), journalists, and politicians.

Following the bomb explosion on the outskirts of Palermo in June 1963, which killed seven policemen, the Parliamentary Commission to Investigate the Mafia Phenomenon in Sicily finally managed to get off the ground. It had been created for the first time in 1962, after 15 years of unsuccessful requests by communist and socialist members of Parliament. Two days after formally installing the commission, however, the Parliament was dismissed, and this bicameral committee would probably not have been re-established if the explosion had not drawn the attention of national public opinion to the problem of the mafia in Sicily (CPMS, 1976: 3-39; Barrese, 1988: 5-54).

After publishing its final report in 1976 (CPMS, 1976), the parliamentary body was re-established in the 1980s under the new name of Commissione parlamentare d'inchiesta sul fenomeno della mafia e altre associazioni similari and has since then de facto become a standing committee of the Italian Parliament. As the new name shows, the committee's competences have been extended to include other mafia-type criminal groups outside of Sicily.

Notwithstanding its quasi-permanent status, the quality and quantity of the activities and products of the so-called Commissione parlamentare antimafia have 
been far from homogenous. On the contrary, they closely depend not only on the degree of attention granted by the national public opinion to the mafia problem but also on the committee's political composition and the alacrity of its president. Informative reports and courageous denunciations were produced especially under the chairmanships of Gerardo Chiaromonte in the late 1980s (see for example, CPM, 1988 and 1989) and, even more so, of Luciano Violante in the early 1990s.

Under the latter's chairmanship during the eleventh legislature (1992-1994), the Commissione parlamentare antimafia heard several important mafia defectors, making their hearings available to the general public (CPM, 1992a, 1992b, 1992c and 1993a), and published numerous reports, after conducting field visits in several parts of Italy and hearing numerous law enforcement and other government representatives and anti-mafia activists (1993c, 1993d, 1994a and 1994b). In 1993 the committee even published a report on 'mafia and politics' (CPM, 1993b), which was the first official document to recognise the relationship existing between the Sicilian mafia and vast sectors of the political and institutional establishment. Reflecting the ebbing interest in the mafia, the parliamentary anti-mafia committees of the following three legislatures have been much less active and supportive of anti-mafia law enforcement action (see for example, CPM, 2001; CPCO, 2003). ${ }^{3}$

Information on mafia infiltration in the legitimate economy and the political sphere can also occasionally be drawn from the hearings and reports of other parliamentary committees of inquiry installed to investigate specific topics of interest. Among the most relevant are there the so-called Commissioni Sindona (1982) and P2 (1984). The first investigated the false kidnapping and murder of the Sicilian financier Michele Sindona, who granted his services to both high-ranking Italian politicians and Sicilian capimafia. The second tried to reconstruct the composition and activities of the secret Freemason lodge P2, which in the 1970s and early 1980s brought together politicians, civil servants, entrepreneurs and members of Sicilian and Calabrian mafia organisations. More recently, since the mid-1990s a bi-cameral committee investigating the 'waste cycle' and its related illicit activities has also been active, producing reports on waste disposal in each of the largest southern Italian regions and on the so-called ecomafie (i.e. mafia and criminal groups involved in waste disposal) (CPR, 2000b; 2003). ${ }^{4}$

3 The reports of the Commissione parlamentare antimafia of the thirteenth and fourteenth legislature can be downloaded from: <http://www.parlamento.it/Bicamerali/1/13/ sommario.htm>.

4 The reports of the Commissione parlamentare d'inchiesta sul ciclo dei rifiuti e sulle attività illecite ad esso connesse active in the thirteen and fourtheen legislatures can be downloaded from: <http://www.camera.it/_bicamerali/nochiosco.asp?pagina=/_ bicamerali/leg14/rifiuti/home.htm>. 


\subsection{The Ministry of the Interior and the DIA}

Since the early 1990s other state bodies have joined the Commissione parlamentare antimafia in regularly publishing information on organised crime in Italy. The Italian Ministry of the Interior began to produce Rapporti annuali sul fenomeno della criminalità organizzata in 1993, though since then the reports have occasionally been published with considerable delay. The most recent report currently available for example concerns the year 2002. ${ }^{5}$ The reports provide qualitative analyses of the organised crime situation in the different Italian regions and, particularly, in southern Italy. More general information on crime and its control can also be drawn from the Rapporti sullo stato della sicurezza in Italia, which are published by the Ministry of the Interior more regularly. ${ }^{6}$

Since 1992 bi-annual reports on organised crime are also published by the Direzione Investigativa Antimafia (DIA), a police force specialised in fighting organised crime, established as part of the Italian Ministry of the Interior in December 1991. Though these reports primarily concern the DIA's activities and operative results, their first part usually illustrates the national organised crime situation on the basis of the investigations recently concluded by the DIA. Due to the poor cooperation among Italian police forces, however, the DIA reports do not take the investigations of the other Italian police agencies into account. ${ }^{7}$

Official sources of information complement a huge amount of journalistic and scientific literature on the mafia, which has grown at a very rapid pace especially since the mid-1980s. Due to its vast volume, this literature cannot in any way be reviewed here. The key scientific studies, which have had a lasting impact on the understanding of the mafia phenomenon, have however been mentioned in the previous section as well as in the introductions to Part I and II.

5 These reports can be downloaded from the website of the Italian police: <http://www. poliziadistato.it/pds/online/documentazione/dipartimento.htm>.

6 These reports can also be downloaded from the website mentioned in the previous note.

7 The Bi-Annual Reports on the DIA's Activities and Operative Results can be downloaded from <http://www.interno.it/dip_ps/dia/semestrali.htm>. 
Organised Crime in Europe

\section{The Peculiarity of the Italian Mafia: Cosa Nostra and the 'Ndrangheta}

Contrary to what most scholars maintained up to the early 1980 s, judicial inquiries carried out since then have proved that formalised mafia groups do exist. Cosa Nostra (Our Thing) in Sicily and the 'Ndrangheta (Society of Men of Honour) in Calabria are the largest and most stable coalitions and are each composed of about 100 mafia groups. Their members are estimated at about 3,000 and 5,000 males respectively.

Though it is not possible to establish clear lines of continuity, recent historical research has demonstrated that antecedents of the contemporary mafia associations existed in the 1880s, if not before. The discovery of new documents in archives and a more objective analysis of the already known papers have demonstrated the presence of mafia groups in Sicily and Calabria since the mid-nineteenth century. As the historian Paolo Pezzino puts it, 'if it is true that these sources have to be examined with great prudence, it is also true that the statements on the existence of well structured associations are so many, and finding confirmation in several judicial proceedings, that it would be difficult to deny their reliability' (1987: 954; for a similar opinion see Lupo, 1988).

\subsection{Secret Brotherhoods}

Cosa Nostra and the 'Ndrangheta possess the distinguishing trait of organisations (Weber [1922] 1978: 48): independent government bodies that regulate the internal life of each associated family and that are clearly different from the authority structure of their members' biological families. Starting from the 1950s, moreover, super-ordinate bodies of coordination were set up - first in the Cosa Nostra, then in the 'Ndrangheta as well. Composed of the most important family chiefs, they are known as 'commissions'. Although the powers of these collegial bodies are rather limited, the unity of the two confederations cannot be doubted. In fact, it is guaranteed by the sharing of common cultural codes and a single organisational formula. According to a model very frequent in pre-modern societies, in fact, the Cosa Nostra and the 'Ndrangheta are segmentary societies (Smith, 1974: 98): that is, they depend on what Emile Durkheim called 'mechanical solidarity' ([1893] 1964: 176-7), which derives from the replication of corporate and cultural forms.

The unity of Cosa Nostra and the 'Ndrangheta is underlined by contemporary mafia defectors. Although they recall the greater autonomy enjoyed by single mafia families before the establishment of superior bodies of coordination, they emphasise the idea that each family belongs to a larger whole; indeed, they take it virtually for granted. 'Substantially', a former member of a Palermitan mafia family recalls, 'Cosa Nostra, as the phrase itself states, is a single and unitary organisation [...] I am therefore staggered by reading in newspapers that there is somebody who 
still doubts this elementary truth that each of us learns the moment he enters the organisation' (TrPA, 1989: 63).

Neither the Cosa Nostra nor the 'Ndrangheta can be assimilated to Max Weber's ideal type of legal-rational bureaucracy, as was suggested by Donald Cressey in the late 1960s with reference to the American La Cosa Nostra (1969). Far from recruiting their staff and organising the latter's work according to the criteria and procedures of modern bureaucracies, mafia groups impose a veritable 'status contract' on their members (Weber, 1978: 672). With the ritual initiation into a mafia cosca (i.e. group), the novice is required to assume a new identity permanently - to become a 'man of honour' - and to subordinate all his previous allegiances to the mafia membership. If necessary, he must be ready to sacrifice even his life for the mafia family. The Catania witness Antonino Calderone, for instance, recalls that during his own affiliation he was told that 'Cosa Nostra [...] comes before everything. It comes before your father and your mother. And before your wife and your children' (Arlacchi, [1992] 1993: 68).

The 'men of honour' in Sicily and Calabria are obliged to keep secret the composition, the action, and the strategies of their mafia group. In Cosa Nostra, in particular, the duty of silence is absolute. Secrecy constitutes, above all, a defence strategy. Since the unification of Italy in 1861 mafia groups have been at least formally criminalised by the state and, in order to protect themselves from arrest and criminal prosecution for their continuing recourse to violence, they have needed to resort to various degrees of secrecy.

The ceremony of affiliation additionally creates ritual ties of brotherhood among the members of a mafia family: the 'status contract' is simultaneously an act of fraternisation (Weber, 1978: 672). The new recruits become 'brothers' to all members and share what anthropologists call a regime of generalised reciprocity (Sahlins, 1972: 193-200): this presupposes altruistic behaviour without expecting any short-term reward. As F. Lestingi, chief prosecutor for the king, pointed out in 1884, mafia groups constitute brotherhoods whose 'essential character' lies in 'mutual aid without limits and without measure, and even in crimes' (1884: 453). Only thanks to the trust and solidarity created by fraternisation contracts does it become possible to achieve specific goals and thus satisfy the instrumental needs of the single members.

As secret brotherhoods using violence, southern Italian mafia associations have remarkable similarities to associations such as the Chinese Triads and the Japanese Yakuza (Murray, 1994; Kaplan, 2003). With their centuries-old histories, articulated structures, and sophisticated ritual and symbolic apparatuses, all these associations - and the American descendant of the Sicilian Cosa Nostra - have few parallels in the world of organised crime. None of the other groups that systematically traffic in illegal commodities have the same degree of complexity and longevity (Paoli, 2002). 


\subsection{The Will to Power}

Cosa Nostra and the 'Ndrangheta share another important peculiarity with the Chinese Triads and the Japanese Yakuza. Unlike other contemporary organised crime groups, they do not content themselves with producing and selling illegal goods and services. Though these activities have acquired an increasing relevance over the past 30 years, neither the trade in illegal commodities nor the maximisation of profits has ever been the primary goal of these associations.

As a matter of fact, at least in the case of southern Italian mafia coalitions, it is hardly possible to identify a single goal. They are multifunctional organisations. In the past 100 years, their members have exploited the strength of mafia bonds to pursue various endeavours and to accomplish the most disparate tasks. Already in 1876 the Tuscan aristocrat Leopoldo Franchetti pointed out the "extraordinary elasticity' of the Sicilian associations of malfattori (evildoers): 'the goals multiply, the field of action widens, without the need to multiply the statutes; the association divides for certain goals, remains united for others' ([1876] 1993: 100).

Among these tasks the exercise of political domination has always been preeminent. The ruling bodies of Cosa Nostra and the 'Ndrangheta claim, above all, an absolute power over their members. They control every aspect of their members' lives, and they aim to exercise a similar power over the communities where their members reside. For a long time their power had a higher degree of effectiveness and legitimacy than that exercised by the state. In western Sicily and in southern Calabria mafia associations successfully policed the general population, settling conflicts, recovering stolen goods, and enforcing property rights.

As late as 1955 , the complementary nature of mafia and state power was acknowledged by one of Italy's most influential magistrates. When Calogero Vizzini, an important capomafia died, the chief prosecutor in the Corte di Cassazione, Giuseppe Guido Lo Schiavo, wrote,

It has been said that the mafia despises the police and the judiciary, but this is incorrect. The mafia has always had respect for the judiciary and for justice, it has accepted its sentences, and has not obstructed judges in their work. In the pursuit of bandits and outlaws it even sided with the forces of law and order [...] Today, we hear the name of an authoritative successor in the position held by don Calogero Vizzini in the secret consortium. May his action aim to the respect of state laws and to the social improvement of all (1955).

Even today, although most of mafia rules are no longer systematically enforced, mafia families exercise a certain 'sovereignty' through a generalised system of extortion. As a state would do, they tax the main productive activities carried out within their territory (Paoli, 2003b: 154-72). Moreover, whenever mafiosi are asked to mediate conflicts, guarantee property rights and enforce rules compatible with 
their own legal order, they do not hesitate to intervene. Despite the much-discussed transformation of the mafia to entrepreneurial activities, contemporary 'men of honour' still take these duties seriously. This point for example is clearly emphasised by Giovanni Brusca, the man who was supposed to become Toto Riina's successor in Cosa Nostra leadership, but who in fact became a mafia witness after his arrest in 1994. Brusca has recounted that he 'helped lots of people recover their cars'. If the stolen vehicle had already been taken apart, his men would steal another that was the same model and colour, in order to satisfy whoever had asked for Cosa Nostra's help (Lodato, 1999: 73).

The political dimension of mafia power is also proved by the fact that in the second half of the twentieth century southern Italy's mafia associations have participated in at least three plots organised by right-wing terrorist groups. Moreover, since the late 1970s Cosa Nostra has assassinated dozens of policemen, magistrates, and politicians. The mafia challenge to state power reached a climax in the early 1990s. In 1992, Cosa Nostra murdered the Palermitan Judges Giovanni Falcone and Paolo Borsellino in two spectacular bomb explosions. In 1993, in an effort to demonstrate the national power of the mafia, a series of terrorist bombings occurred - for the first time out of traditional mafia strongholds - in Rome, Florence, and Milan (Stille, 1995).

\subsection{The Incomplete Entrepreneurial Transformation}

Despite their power, mafia fraternities have not been able to guarantee themselves a monopoly in any sector of the illegal economy outside of southern Italy. In the early 1980s, Cosa Nostra families played a pivotal role in the transcontinental heroin trade from Asia to the United States via Sicily. But in the second half of that decade, the Cosa Nostra lost this position after being targeted by law-enforcement investigations and replaced in the United States market by a plethora of Mexican, Chinese, and, more recently, Colombian heroin suppliers (Paoli, 2003b: 215-16).

In the case of Cosa Nostra, its power is not unchallenged even within its strongholds. Given the extreme rigidity of their recruitment policies, in fact, Cosa Nostra families often find themselves in a minority position with their local competitors and are hence unable to control the whole underworld. This difficulty was admitted even by Giovanni Brusca:

Many believe that Cosa Nostra heads all criminal activities. That in Palermo or in Sicily every illegal activity is controlled by the mafiosi. People believe that prostitution and burglaries, bank robberies, and car thefts are all entries in the budget of the Mafia Inc. Those that I have just listed are external activities, known about, tolerated, and controlled by men of honour. But they are separate worlds, which only rarely come into contact with each 
Organised Crime in Europe

other. In some cases, there might be some collaboration, but this is only in very special cases (Lodato, 1999: 67).

Despite the growing relevance of economic activities, "the mafia has not become a set of criminal enterprises' (Becchi and Turvani, 1993: 156). Its history as well as its cultural and normative apparatus prevent this transformation and today constitute a constraint as much as a resource. By building a strong collective identity, shared cultural codes and norms enhance group cohesion and create trustful relationships among mafia members. The reliance on status and fraternisation contracts, which are non-specific and long-term, produces a high degree of flexibility and makes the multi-functionality of mafia groups possible. The same shared cultural codes and norms also represent, however, a powerful brake on entrepreneurial initiative. The prohibition on exploiting prostitution, for example, which exists in both confederations (Falcone, [1991] 1993: 115), has blocked the entrance of the Sicilian and Calabrian mafia groups into what has become one of the most profitable illicit trades: the smuggling of humans and the exploitation of migrants in the sex industry.

Especially constraining is one of the preconditions for recruitment: only men born either in Sicily or in Calabria or descending from mafia families can be admitted as members. This rule has long prevented Cosa Nostra and 'Ndrangheta families from adding new members with the experience necessary to compete in the black markets for arms, money, and gold. Rigid recruitment criteria have also hampered the geographical expansion of mafia power. Cosa Nostra, for example, prohibits settling families outside of Sicily. This self-imposed rule, which aims to strengthen the cohesion of the mafia consortium, has limited its involvement in the international narcotics trade - currently the largest of the illegal markets. 'Ndrangheta families, thanks to their extensive branches in northern Italy and abroad, played a larger role in narcotics trafficking in the 1990s, importing large quantities of cocaine and hashish from Latin America and North Africa; today, however, the 'Ndrangheta faces new competition from foreign and Italian traffickers with more direct connections to drug-producing and transit countries (Paoli, 2003b: 217).

The 'will to power' of the mafia associations also negatively affects security and business decisions, as a leading Palermitan prosecutor pointed out in 1992:

The true goal is power. The obscure evil of organisation chiefs is not the thirst for money, but the thirst for power. The most important fugitives could enjoy a luxurious life abroad until the end of their days. Instead they remain in Palermo, hunted, in danger of being caught or being killed by internal dissidents, in order to prevent the loss of their territorial control and not run the risk of being deposed. Marino Mannoia [a former mafia member now cooperating with law enforcement authorities] once told me: 'Many believe that you enter into Cosa Nostra for money. This is only part of the truth. 
Do you know why I entered Cosa Nostra? Because before in Palermo I was Mr. Nobody. Afterwards, wherever I went, heads lowered. And to me this is priceless' (Scarpinato, 1992: 45).

As a result, since the early 1990s Cosa Nostra and 'Ndrangheta families have extracted a growing percentage of their income from entrepreneurial activities that depend on the exercise of regional political domination. They practice systematic extortion in their communities and, thanks to intimidation and collusion with corrupt politicians, they have struggled to control the market for public works (see infra).

Unlike other western forms of organised crime, the meaning (and danger) of Sicilian and Calabrian mafia associations cannot be limited to their involvement in illegal markets. Their peculiarity lies in their will to exercise political power and their interest in exercising sovereign control over the people in their communities.

\section{Other Forms of Organised Crime in Italy}

In addition to the Sicilian Cosa Nostra and the Calabrian 'Ndrangheta, two other clusters of crime groups are usually referred to as organised crime in Italy: 1) the 'galaxy' of mafia-like and gangster-like groupings in Campania, collectively known as camorra and 2) the multiplicity of criminal groups, gangs and white-collar criminal networks operating in Apulia.

\subsection{The Camorra}

The camorra consists in a variety of independent criminal groups and gangs. Some of them are well-established family businesses that, as much as Sicilian and Calabrian mafia groups, claim to exercise a political dominion over their neighbourhoods and villages and systematically infiltrate local government institutions, at some point enjoying the protection of high-level national politicians as well. Other camorra groups are less lasting formations that have developed around a charismatic chief, usually a successful gangster. Finally, there are also loose gangs of juvenile and adult offenders, which - according to police sources - rather belong to the sphere of common crime than to that of organised crime (Ministero dell'Interno, 2001a: 60-5).

To strengthen their legitimacy and cohesion, many of the above groups frequently resort to the symbols and rituals of the nineteenth-century camorra. This was an organisation sharing several cultural and organisational similarities with its Sicilian and Calabrian counterparts, though it distinguished itself on its concentration in the city of Naples, the capital of the region Campania, and its plebeian background. 
Unlike Cosa Nostra and the 'Ndrangheta, however, the contemporary Campanian underworld does not directly derive from its nineteenth-century forerunner. As Isaia Sales puts it, 'if camorra means a criminal organisation that ruled over Naples' popular and plebeian strata, we can safely say that it started and ended in the nineteenth-century' (2001: 468).

The camorra was 'born again' in the 1960s thanks to the expansion of smuggling in tobacco and later, in drugs. In the 1980s, several camorra groups and short-lasting coalitions of groups (above all, the Nuova Camorra Organizzata and the Nuova Famiglia) then gained great wealth and power with the appropriation of the public money flows invested in Campania after the earthquake of 1980 (Sales, 1993; Monzini, 1999). Despite their extensive infiltration of the legitimate economy and the public administration, however, contemporary camorra groups have not succeeded in establishing stable coordination mechanisms such as those of the nineteenth-century camorra or of the Sicilian and Calabrian mafia associations. As a result, Campania has had the highest rate of murders and violent crime in all of Italy for more than a decade.

The heterogeneity and anarchy of the Campanian underworld is also proved by the great variety of entrepreneurial activities the local crime groups are involved in. The most powerful camorra clans are still able to condition the local legitimate economy, despite the devastating investigations conducted by law enforcement agencies in the 1990s. The smaller groups and gangs engage in all sorts of illegal activities - from extortion to fraud, from drug trafficking and dealing to loansharking, from counterfeiting to the exploitation of prostitution - and are ready to resort to violence whenever they see their 'turf' and activities being threatened (Ministero dell'Interno, 2001a: 60-75).

\subsection{The So-Called Apulian Organised Crime and Other Groups}

The development of Apulian 'organised crime' goes back to the 1970s when the region became Italy's major import point for smuggled cigarettes and was 'colonised' by neighbouring mafia and camorra groups. In the following years, indigenous crime groups and gangs sprang up in different parts of Apulia. The most successful of these entities was for a long time the Sacra Corona Unita, a consortium of about ten to fifteen criminal groups and gangs from southern Apulia, which was founded in 1983 (Massari, 1998). Contrary to the accounts of the media, the Sacra Corona Unita never controlled the whole Apulian organised crime; despite its imitation of the 'Ndrangheta's structure and rituals, its cohesion and stability have always been much lower. Today, after the defection of some of its leaders and the arrest of most of its members, the Sacra Corona Unita no longer exists as a single viable organisation (Ministero dell'Interno, 2002: 57-64).

Notwithstanding the decline of the Sacra Corona Unita, illegal business activities go on. Up to the early 1990s tobacco smuggling was the main source of revenue 
for most Apulian criminal enterprises. Since then, however, these have diversified their investments, exploiting their strategic geographical position to smuggle drugs and migrants from the close Balkan countries. In the last few years, as the improved cooperation of Italian and Albanian police forces resulted in an intensified repression of tobacco smuggling, Apulian crime groups have also started to engage in extortion, usury, robberies and counterfeiting, to compensate their loss of revenues.

A few other criminal coalitions and gangs located in eastern and southern Sicily and in northern Calabria, such as the Stidda in the Agrigento and Caltanissetta provinces or the Laudani, Cursoti and Pillera-Cappello in Catania, are also occasionally referred to as organised crime or mafia. Their internal cohesion and political and economic resources are much lower than those of Cosa Nostra or 'Ndrangheta families, though Sicilian groups have been from time to time able to threaten the supremacy of the local Cosa Nostra families due to the larger number of members and their readiness to use violence (Ministero dell'Interno, 2002).

\subsection{The New 'Foreign Mafie' and Inconspicuous Players}

The expressions 'organised crime' and 'mafie' are also increasingly used to refer to foreign criminals operating in Italy. For example, the last bi-annual reports on the activities of the Direzione Investigativa Antimafia, a police body specialised in the fight against organised crime, all contain a chapter devoted to 'criminalità organizzate straniere' (foreign organised criminalities) (see Ministero dell'Interno, 2001b, 2001c and 2002).

Since the early 1980s, Italy has indeed undergone a process of internationalisation and ethnicisation of its illegal markets. This trend, which started in other western European countries in the 1950s, took place very rapidly in Italy from the mid-1980s on, when Italy also became the destination of considerable migration flows. All over Europe, the internationalisation of illegal markets was strongly accelerated in the 1990s by the European integration process and the abolition of border controls as well as by the radical transformations that occurred in what was once called the 'Second World': the former Soviet Union and eastern Europe. Paradoxically, in Italy the internationalisation of illegal markets was also favoured by the successes of the law enforcement forces that in the 1990s dismantled the most consolidated branches of mafia groups in the centre and north of Italy. The empty spaces, once controlled by the powerful clans of the Calabrian 'Ndrangheta and the Sicilian mafia, are today occupied by various groups and gangs of different ethnic origin and make-up (Paoli, 2000: ch. 4).

As a result, today in Milan like in Rome, Frankfurt, London or Amsterdam, illicit goods and services are offered and exchanged by a multiethnic variety of people. Next to mafiosi and local criminals, one finds illicit entrepreneurs coming from 
all parts of the world. A few of these 'ethnic' criminals - in particular, the Chinese ones - tend to exercise a sort of political power within their own communities (Suchan, 2001) - much like the Sicilian and Calabrian mafiosi in their strongholds. However, most of the foreign criminal groups and actors active in Italy have no claim to exercise a political authority. They merely content themselves to make fast money by trading in illicit commodities and/or reinvesting dirty money from their home countries in the European Union and, specifically, in Italy.

Their internal composition is also much different to that of southern Italian mafia families. Foreign crime groups and gangs active in Italy hardly have the longevity and organisational complexity of southern Italian mafia associations. Some of them are family businesses or organisations cemented by profit-making or by shared revolutionary or ideological goals; many more are loose gangs, founded on ties of friendship and locality. These are usually small, ephemeral enterprises that can be most correctly described as 'crews': loose associations of people, which form, split, and come together again as opportunity arises. In crews, positions and tasks are usually interchangeable and exclusivity is not required: indeed, many crew members frequently have overlapping roles in other criminal enterprises (Paoli, 2002; Gruppo Abele, 2003).

Illegal market groups and crews are by no means composed exclusively of foreigners. Besides the members of mafia and pseudo-mafia groups, at all levels of Italy's illegal markets we also find people belonging to the mainstream population with no previous underworld connections. It is enough to say that two of the largest cocaine importers in the late 1990s were not mafia members, nor foreigners, but Italians who merely belonged to the sphere of white-collar crime. The first was a Milanese, who invested money earned from loan-sharking in the drug business and was able to import 600 to 800 kilograms of cocaine directly from Colombia each time. The second one was a former bank manager from Naples, who was responsible for several 400 to 700 -kilogram cocaine shippings. Both of them supplied a plurality of wholesale traffickers, including members of southern Italian mafia groups, who resided in several parts of the country (Paoli, 2000: 110-15).

As such, the 'new' illegal market players better fit into the 'entrepreneurial' definitions of organised crime that are en vogue in northern and central Europe than into the mafia-centred understanding of organised crime that is widespread in Italy. Despite the lack of empirical proof, however, foreign illicit entrepreneurs are all too frequently labelled as mafia and believed to be organised in the same way as Cosa Nostra and the 'Ndrangheta. Sooner or later - in Italy and elsewhere - we will have to discuss seriously these assumptions and the opportunity of employing the instruments developed in anti-mafia campaigns in the fight against this 'other' form of organised crime, which - if we take the Italian understanding of the concept as a parameter - is not as organised as it is very often made out to be. 


\section{The Normality of Illegal Markets}

As all modern societies, Italy too has a criminal economy. As much as the underground economy of which it is a part, the criminal economy is a by-product of the state's efforts to regulate, tax, and supervise the economic activity carried out within its territory. The criminal economy, in particular, involves the production and circulation of illegal goods and services as well as the illegal production and distribution of legal commodities that are heavily regulated by the state.

\subsection{Sectors and Figures}

The production and sale of only two goods are - with few, limited exceptions - outlawed by most states and international bodies: some psychoactive drugs, and human beings. As a consequence of state and international bans, all exchanges of these 'commodities' are bound to take place on the 'wrong side of the law', and illegal markets have therefore developed.

Following international trends, a national illegal market in cannabis developed in Italy in the late 1960s. In the following decades, heroin, cocaine, and, more recently, ecstasy have also been consumed and traded on a large scale. The drugs market most probably represents Italy's largest illegal market (Paoli, 2004). According to Guido Rey's estimates (1992; see also Becchi and Rey, 1994), in 1990 the turnover of the heroin market exceeded ITL 7,000 billion ( $€ 3,500$ million at the current fixed exchange rate). Wholesale and retail trade in cocaine allegedly produced a turnover ranging between ITL 1,200 and 4,800 billion ( $€ 600-2,400$ million), whereas the value of the cannabis market was estimated at ITL 380 billion ( $€ 190$ million). As cocaine and cannabis consumption has considerably increased since then, the current turnover of the two drug markets is most probably larger than the figures presented by Rey (Paoli, 2004).

The smuggling of human beings became a flourishing business in the early 1990s. Italy's long and relatively unguarded coastline as well as its closeness to eastern European and Middle Eastern countries have made it a convenient landing place for thousands of migrants smuggled into the European Union from the former Second and Third World. Some of these migrants - though it is impossible to say exactly how many - are then forced into prostitution or otherwise exploited in both the criminal and informal sectors of the economy (Monzini, 2002; Monzini, Pastore and Sciortino, 2004).

Additionally, many other goods and services - ranging from arms to toxic waste, jewels, and counterfeited merchandise, from prostitution to gambling to money laundering - are marketed daily in violation of specific trade regulations and restrictions. Still others are exchanged without paying excise taxes: for example, tobacco has been smuggled on a large scale into Italy ever since the 1960s. In 1994 the Guardia di Finanza (customs police) estimated that the yearly revenue 
from smuggling tobacco was more than ITL 1,100 billion ( $€ 550$ million) with a loss of about ITL 1,100-1,200 billion in taxes (value-added tax and excise taxes) (Ministero dell'Interno, 1994: 473-4).

Given the variety of commodities and suppliers involved, it is difficult to estimate the overall revenue of the criminal sector. Though exorbitant estimates can often be read in the press, the revenue from the criminal sector in Italy represents only a small fraction of the total revenue of the underground economy (which additionally includes the much larger informal economy). Italy's criminal economy is not significantly larger than that of other Western countries.

Some criminal activities - such as the smuggling of tobacco and human beings - do seem to be particularly prevalent in Italy, above all due to its extensive coastline and geographical position. Southern mafia associations and other organised crime groups also engage in illegal transfers of money - through extortion, embezzlement, fraud, or robbery, for example - that are not usually included in the definition of the underground and criminal economies, because they do not create value but merely transfer it from one person to another. Extortion practices, in particular, constitute one of the most important sources of revenue for southern Italian mafia and pseudo-mafia groups. According to estimates made by the Direzione Centrale della Polizia Criminale, extortion produces an annual revenue of at least ITL 1,400 billion (€ 700 million) (Rey, 1992).

On the whole, however, crime in Italy does not pay much, according to the most comprehensive and reliable estimates of the criminal economy. Working in cooperation with police forces and several other state agencies, in 1992 Guido Rey (1992; see also Becchi and Rey, 1994: 25), then president of the National Institute of Statistics (ISTAT), concluded that the total revenue from criminal enterprises was about ITL 30,000 billion ( $€ 15$ billion) in 1990, with roughly 150,000 persons variously involved in these activities.

\subsection{Illegal Markets Suppliers and the Constraints of Illegality}

As already mentioned, southern mafia associations are far from being the only actors in the criminal sector of Italy's underground economy. Even though they control many (but not all) contra legem activities in the areas they dominate, they do not have monopolistic control over the national illegal markets. Apart from Cosa Nostra and 'Ndrangheta members, a variety of different groups, gangs and individuals participate in Italy's illegal economy. As in most other European states, this is open and competitive, as shown by the fact that most of its enterprises are price-takers rather than price-givers. That is, none of them are able to influence the commodity's price appreciably by varying the quantity of the output sold (Paoli, 2004).

The 'disorganised' nature of Italy's illegal markets is due to the fact that their enterprises are subject to the 'constraints of illegality' (Reuter, 1983) and thus tend to adopt a small and flexible organisation and to be ephemeral. (These constraints, 
which are valid for all countries having a relatively stable and effective government, will be explained in the comparative synthesis of Part II).

Even southern Italian mafia families are subjected to the constraints deriving from the illegal status of products and, when they deal in drugs or other illegal commodities, they do not operate as monolithic productive and commercial units. On the contrary, their members frequently set up short-term partnerships with other mafia affiliates, or even non-members, to carry out illegal transactions. These partnerships are far from being stable working units that could be compared to the branch offices of a legal firm. Their composition frequently changes depending on the moment at which deals take place or on the availability of single members. After one or a few illegal transactions some teams are disbanded, while others continue to operate for a longer time, eventually changing their composition to some extent (Paoli, 2003b: 144-48).

Emblematic in this respect are the large-scale, transcontinental, heroin-trafficking activities reconstructed during the first Palermo maxi-processo (maxi-trial) in the 1980s. The descriptions provided by the media often suggest that this business was dominated by Cosa Nostra as a single organisation. However, a careful reading of the trial papers reveals that the various stages of the production and distribution process were organised by members of different families. The latter, far from considering themselves as part of a single economic unit, were very jealous of their own networks of clients or suppliers and of their particular specialisations. On this matter, the public prosecutors belonging to the first pool of anti-mafia investigators stated:

Inside Cosa Nostra, structures having de facto autonomy, but which are functionally linked, have been created to organise the different phases making up the complex drugs trade, while the 'men of honour' who do not have operational responsibilities in the trade may contribute to it financially, sharing profits and risks to different degrees (TrPA, 1985: 1887).

By creating a climate of trust, common membership of Cosa Nostra enhanced the development and consolidation of business exchanges. However, these can hardly be compared with the relationships between the departments of a normal corporation. Instead, they were transactions taking place between distinct enterprises in such a way that, despite the mafia brotherhood ties, compliance with the contracts was guaranteed by all the means typical of the mafia, including the threat and the use of violence. 
Organised Crime in Europe

\section{Mafia Infiltration of the Legitimate and Informal Economy}

Whereas Italy's criminal economy is not significantly larger than that of other western countries, Italian organised crime's infiltration of the legitimate and informal economy certainly is. This has to do with the very nature of Italian mafia groups and their claim to exercise a political dominion within their communities, which is mainly expressed today in the extraction of a 'protection tax' - the so-called pizzo. ${ }^{8}$ All the families associated with Cosa Nostra and the 'Ndrangheta and many camorra groups as well force - by fair means or foul - many (if not most) of both the licit and illicit enterprises that are active in their area of competence to pay this on a regular basis.

There are many different ways of paying the pizzo, though this usually takes the form of a (forced) transfer of money (known as a tangente, i.e. kickback). This can also be a payment in kind, for example, by forcing a company to take on a guardiania (i.e. protection services) that is then paid for by putting a 'man of honour', or a client of his, on the company's payroll, or the acquisition of supplies from firms controlled by the mafiosi. Sometimes the company subjected to extortion is also forced to accept the participation of mafia members or their associates in jobs for which it has a contract (PrPA, 1993: 219; TrRC, 1994).

According to the Lawyer General of Reggio Calabria, 'all business activities in towns or provinces [of Calabria] are subjected to the extortion racket: industrial firms, commercial businesses, farms, and even the professions' (CPM, 1993c: 8). In Sicily, Calabria and Campania, in particular, mafia and pseudo-mafia groups claim a percentage on every building project carried out on their territory. 'The rule', the Sicilian pentito (mafia defector) Leonardo Messina states,

is that any firm starting a job on the territory of a family must contact a man of honour of that family, in order to establish either the percentage to be paid to the mafia family, considering the overall value of the work to be accomplished, or the payment of a kickback - so as to say - 'in kind' (PrPA, 1992: 60).

\subsection{The Involvement in the Construction Business}

In the building sector, mafia and camorra groups do not usually content themselves with the extraction of a sum of money. The 'payments in kind' that Messina mentions are frequent, one of their functions also being to maintain the power of the

8 Literally a 'beakerful', the word 'pizzo' originally referred to the right of the overseer to scoop from the grain being threshed by the peasants (see Fentress, 2000: 163). 
organisations. Since the 1950s, for example, the Calderone brothers of the Cosa Nostra family in Catania protected the largest local building companies and, in addition to ITL 1 million monthly kickback gave work to thousands of people in the building yards (CPM, 1992a: 333-4).

From the 1950s onwards, Cosa Nostra groups also set up their own companies and pressed claims to become directly involved in both small and large building sites. By the early 1970s, judge Giovanni Falcone noted, the building industry in the city of Palermo was almost entirely in the hands of the mafia: 'Mafia organisations entirely control the building sector in Palermo - the quarries where aggregates are mined, site clearance firms, cement plants, metal depots for the construction industry, wholesalers for sanitary fixtures and so on [...]' (Falcone and Turone, 1982).

Starting from the late 1960s, the same kind of development also took place in Calabria. When large building projects were launched in the region by a Calabrian Minister for Public Works, the national building companies that won these tenders were immediately targeted by the mafia groups responsible for those pieces of territory, which claimed the payment of a 'protection tax' through intimidation and threats. Realising the high potential of this area of business to generate money, mafia groups did not restrict themselves to only collecting the pizzo, but also demanded more direct participation in the work itself. For example, they set up small building firms to gain subcontracts for the site clearances (PrRC, 1995: 279ff.). This strategy of infiltration in the building sector was largely successful and since the 1970s building companies owned by Sicilian and Calabrian mafiosi and Campanian camorristi have been able to gain subcontracts in many, if not in most, of the major public building projects taking place on their territories.

Mafia companies have also been active in the illegal construction business, building thousands of square metres without the necessary authorisations, in protected areas, or without respecting security standards. Unauthorised housebuilding (abusivismo edilizio) is a common activity, especially in southern Italy. Between 1994 and 1998 alone, for example, 232,000 unauthorised houses were built, with a surface area of over 32.5 million square meters and a real estate value of approximately $€ 15$ billion (Ministero dei Lavori Pubblici, 2000).

Mafia companies are far from being the only or even the major actors of the abusivismo edilizio. Much of the unauthorised house-building is due to 'ordinary' Italians with no direct ties to organised crime. There is no doubt, however, that mafia building companies have profited considerably from the rooted disrespect of the law that characterises the whole building sector in large parts of southern Italy. Moreover, members of mafia and other criminal groups frequently earn money even if their companies are not directly involved in the construction of unauthorised buildings. Especially in Campania, but to a lower extent in the three other southern Italian regions most affected by organised crime, camorra and mafia groups control the sand extraction and the production of concrete and 
sell this material at an increased price to all building companies in their areas of settlement (CPR, 1998).

Undoubtedly however, the building companies owned by mafiosi draw much of their profits not from the petty unauthorised house-building but from the manipulation of large-scale public tenders. The novelty of the 1980s and 1990s was, indeed, represented by the involvement of mafia representatives in the comitati d'affari, originally formed of politicians and entrepreneurs, which had controlled the bidding processes of large-scale public works all over the country for many years. As the judges of the southern Calabrian city of Palmi noted with reference to the construction of a power plant by ENEL (Italy's Electric Public Company) in the Gioia Tauro Plain 'the mafia has not only infiltrated into subcontracting, but into the direct management of the works [...] through liaison elements linking the private [building] firms, the state company afflicted by party kickback policies, politicians and the representatives of imprese a partecipazione mafiosa [companies in which mafiosi had a share]' (PrPL, 1993: 1987-8).

Thus mafia conditioning no longer takes place only 'downstream', at the end of the economic process of public investment (subcontracts and extortions), but also 'upstream' at the beginning of the process, with decisions made jointly by mafia representatives together with the state agencies and the large building companies that are particularly interested in obtaining large contracts for public works (ibid.: passim). In western Sicily, for example, a sort of 'duopoly' was established in the late 1980s and early 1990s: the public works market was subject to the complete top-downwards control of two strong subjects - Cosa Nostra and the comitati d'affari - which had joined forces in a kind of symbiosis cemented by silence and complicity (TrPA, 1991, 1993 and 1998; Ministero dell'Interno, 2001c: 15-6).

\subsection{The Involvement in the Illegal Traffic in Waste}

During the 1990s, as the state investment for large-scale public works rapidly decreased, mafia and camorra groups increasingly became involved in the waste disposal business. This activity, which is often carried out in full or partial disrespect of the law, is a big business. According to the Parliamentary Committee to Investigate the Waste Cycle and its Related Illicit Activities, 108 million tons of waste are produced every year in Italy and about 35 million of them are disposed of incorrectly or illegally, with an estimated turnover of about $€ 7$ billion and a tax loss of at least $€ 1$ billion (CPR, 2000b: 7-8). According to this parliamentary body, the weakness of the environmental criminal legislation and the mildness of the criminal sanctions have made the illegal waste disposal particularly attractive for organised crime groups (CPR, 2000a: 33).

Companies owned or protected by members of the Sicilian Cosa Nostra, the Calabrian 'Ndrangheta and the Campanian camorra are very frequently involved in the waste collection and transportation and the unauthorised or irregular manage- 
ment of waste dumping grounds in southern Italy (CPR, 2000b: 15, 31). They are, instead, more rarely present in the most technically advanced sectors of waste recycling and thermo-destruction.

According to the Prefect of Naples, 90 per cent of all companies involved in the waste collection and transportation in Naples area have ties with organised crime (CPR, 2000b: 25). Illegal dumping grounds are, indeed, particularly widespread in Campania, which, according to the parliamentary committee of inquiry, has a bent to become 'Italy's trash can'. Quarries, holes in the ground and even open fields are used by camorra companies to hide waste of different types, including toxic and dangerous waste. In an investigation of the Naples Prosecutor's Office, the involved camorra group, the so-called clan dei Casalesi, turned out to have disposed of 11,000 tons of dangerous waste between 1994 and 1996. The camorra's involvement in illegal waste disposal is so intense that some camorra-related companies have started to 'export' waste to illegal dumping grounds in other regions, most frequently in Latium, Abruzzo and Basilicata (CPR, 2000b: 25; see also Ministero dell'Interno, 2001c).

In Campania, there is often a clear superimposition between the 'cement cycle' and 'waste cycle': i.e. camorra members and their front-men are involved in both the illegal construction and waste disposal businesses. In fact, the sand that is necessary to produce concrete is often extracted by camorra companies from illegal quarries, which are then filled with waste of different type, to try to hide the soil subsidence (CPR, 1998).

However, as the Commissione parlamentare d'inchiesta sul ciclo dei rifiuti e sulle attività illecite ad esso connesse notes, the waste business is by no means monopolised or controlled by organised crime:

It would be a serious mistake to relate all illicit activities in the waste disposal to the so-called 'ecomafia', as the data gathered by the Commission in its hearings clearly demonstrate. There are, in fact, companies not related with organised crime that however seem to found all their activities on an incorrect management of waste. Forms of micro-crime are also widespread throughout Italy. Relating all illegality to the 'ecomafie' would thus mean forgetting a great part of the illicit activities (CPR, 2000b: 10).

Even the investigations focusing on mafia-type organised crime show that camorra and mafia groups usually provide waste disposal services to legal companies willing to do business with mafiosi because they are able to spare considerable sums of money by getting rid of dangerous waste irregularly. In fact in most cases, as shown by the summaries of investigations recorded by Legambiente in its annual reports (2001 and 2002), the waste to be hidden in illegal dumping groups in the Mezzogiorno is produced in northern Italy by fully legitimate firms. 
Organised Crime in Europe

\subsection{Mafia Infiltration of Other Sectors of the Legitimate Economy}

Since the 1980s the families and members of both Cosa Nostra and the 'Ndrangheta as well as the most successful camorra clans have employed a significant portion of the money accumulated with illegal activities to buy - either directly or through fronts - a large number of small and medium-sized companies in their area of dominion. According to data collected by the Confcommercio in 1992, about 4,000 Sicilian retail shops - about 10 per cent of all those active on the island - are either run or directly controlled by members of crime groups. It is an estimate that is hard to verify. What did emerge very clearly in a survey commissioned by the association of the Youth Branch of the Confindustria (Italian Industrialists' Association) in 1993 was that 55 per cent of the owners of Calabrian, Sicilian and Campanian firms claimed that in their particular sphere of activity it is current practice for businesses to yield a quota of their ownership to a variety of people who are tied to illegal or suspect businesses (Ministero dell'Interno, 1994).

In some contexts, Cosa Nostra and the 'Ndrangheta families have even succeeded in establishing monopolies, which are not imposed through violence, but are built on the effective ownership of all the local firms in a certain area. For more than a decade, for example, the market for new and old vehicles in Reggio Calabria was controlled by front-men of a 'Ndrangheta family. Having no need to make any immediate profits and being able to rely on cash from illegal sources, the mafia-controlled firms managed to put other agencies out of business in a very short amount of time since these could not afford to give the discounts that the former offered (PrRC, 1995: 6318-405).

In other cases, both money and violence are employed - in variable combinations - to monopolise licit activities in a local context. This was, for example, the strategy of other powerful 'ndranghetisti, the De Stefano brothers, who during the 1980s controlled virtually the entire Reggio Calabria wholesale meat market. Through intimidation and threats, they forced butchers and supermarkets to buy meat from their companies (TrRC, 1994: 124-6). The same combination of money and violence was also employed by three other capimafia - Francesco Serraino, the 'mountain's king', Rocco Musolino and Francesco Antonio Gioffré - to gain control of the wood industry in the Aspromonte mountain as well as by other 'ndranghetisti to acquire many of the shops located in Reggio Calabria's principal avenue (CPM, 2000: 72-3). Lastly, largely neglecting profit maximisation strategies, the leaders of mafia families - especially in Calabria - have bought large pieces of land in their communities of residence (Paoli, 2003b: 153-4). 
Organised Crime in Italy

\section{Mafia and Politics}

Mafia infiltration of public administration and political institutions also has no parallel either in western Europe or probably in most eastern European countries as well. Though mafiosi's relationship with politicians and government officials has lost its rooting in a common Weltanschauung and is accepted by shrinking portions of public opinion, it is mainly due to these illicit connections and alliances that the recent decline of Cosa Nostra, 'Ndrangheta and camorra families has been slowed down.

\subsection{The Long 'Cohabitation' and its Slow Delegitimation}

Despite the progressive delegitimation of mafia values and norms since the end of the Second World War, the 'cohabitation' between state and mafia powers remained unabashed, at least at the local level, well into the 1960s and 1970s. Especially in Sicily, up to the 1970s many 'men of honour' were actively involved in political life and held important political positions at the city, regional, and even national levels. As late as November 2000, for example, the former Christian Democrat senator, Palermo's vice mayor and commissioner Vincenzo Inzerillo, was sentenced to a nine-year conviction as a 'made' member of a Palermitan Cosa Nostra family (Gazzetta del Sud, 22 November 2000).

The pool of politicians that was not ritually affiliated, but whom the Cosa Nostra families were able to influence, was even wider. Among them was Salvo Lima, who was mayor of Palermo between the 1950s and the 1960s, and Vito Ciancimino, who was first commissioner for public works in Lima's administration and then took over as mayor when Lima was elected as a member of the national Parliament in 1968 (Vasile, 1994; Santino, 1997).

Even when the superimposition of roles was not total, relations between Sicilian 'men of honour' and the more entrepreneurial politicians became closer and more equal beginning in the mid-1950s. This movement was favoured by the common social origins and shared will of these men to conquer power by all means available. Between politicians and mafiosi there was no longer a gap in social extraction, education, and lifestyle - factors that had separated most of the latter from liberal notables. In fact, the politicians who reached the top in the parties and local administrations in the post-war period were homines novi coming from medium to low, if not humble, backgrounds, like most members of mafia groups - and like the mafiosi they wanted to make careers at any cost (Paoli, 2003b: 196-7).

In Calabria electoral and business pacts between capimafia and state representatives were often underwritten in the shadow of the Freemasonry, into whose lodges - both the official and the secret, parallel ones (the latter being labelled 'deviated' in Italian) - the 'Ndrangheta bosses entered massively after 1970. Thanks to the powers 
of mediation of the Freemasonry, even in Calabria the pacts between politicians and mafiosi became - as in Sicily from the 1950s - more 'equal' (ibid.: 198-9).

In both regions, the power of the politicians was apparently much stronger than that of the capimafia and basically consisted in their ability to condition the allocation process of state resources. In order to do so, however - and it was in this that their intrinsic weakness lay - they needed the votes that the mafiosi gathered for them during electoral competitions. In this respect, the 'Ndrangheta's blackmailing power is still today particularly high, even higher than that of Cosa Nostra. It has, in fact, been estimated that in the small and medium-sized southern Calabrian municipalities, the ruling mafia family can control up to 40 per cent of the votes, while this percentage decreases to 15 to 20 per cent in the larger towns (Arlacchi, 1988: 137-40). This assessment was also confirmed by the former mayor of Reggio Calabria, Agatino Licandro: in his opinion, among the members of the city council 'there are at least 10 to 15 per cent who are consciously elected with mafia votes' (CPM, 1993c: 58).

From the early 1980s on, the two power structures forming mafia and political elites have increasingly unified in Calabria. Instead of supporting external politicians, the major 'Ndrangheta families have often mobilised their electoral weight to back mafia members standing for office, or people linked by close kinship ties to the family chief or high-ranking members. The men leading the De Stefano mafia group since the mid-1980s exemplify very clearly this phenomenon, which has been described as 'the internalisation of representation' (Arlacchi, 1988: 176-7). Since Paolo De Stefano's death in 1985, this mafia family, the largest in Reggio Calabria, has been headed by his cousin, the lawyer Giorgio De Stefano, who represented the Christian Democrats on the city council for many years, and Paolo Romeo, a member of Parliament for the Social Democratic Party (PSDI) for several legislatures (PrRC, 1993, 1995).

In contrast, in Cosa Nostra, the overlapping of relations between the mafia and politics, which had been common practice since the 1950s, progressively broke down with the balance going mainly in the favour of the mafia until the early 1990s. Emboldened by the billions accumulated through heroin trafficking, Cosa Nostra chiefs increased their demands on politicians from the late 1970s on, trying to control the decisions of the public administration in an increasingly pressing and arrogant way and claiming favours of all kinds at the national level. And for the first time they also began to kill the politicians who did not honour the pacts underwritten with them, to punish their betrayal and to warn the remaining referents (PrPA, 1995b).

This open use of violence revealed not only a growing mafia arrogance, but also the deteriorating quality of relations between the mafia and political power. That is to say, post-war socio-economic and cultural modernisation processes fostered the dissolution of a broad mafia subculture that was previously shared by both mafiosi and politicians. In turn, this has led to a new paradigm of behaviour based 
on utilitarian calculations. In other words, before entering a deal, each side now carefully assesses the financial, electoral, or judicial gains that it could draw from the other. This change has been accompanied, in Sicilian mafia families, by a growing distrust and lack of respect toward the political class (Paoli, 2003b: 200-2).

\subsection{The Upheavals of the 1990s: Return to the Cohabitation?}

The deterioration of relations between the mafia and politics is the result of a slow process of delegitimation that has invested mafia power during the whole post-war period. Initially prompted by small enlightened minorities, this change has recorded a sharp acceleration from the early 1980s onward.

A truly mass, interclass social movement against the mafia emerged for the first time in Italy's history in 1982. In September of that year, General Carlo Alberto Dalla Chiesa, who had been sent to Palermo in June as a high commissioner to combat the mafia, was killed, together with his wife and driver. The public reacted with outrage. Two weeks after the Dalla Chiesa murder, which followed the assassination of 15 other state officials and politicians over the previous three years, the La Torre Act was passed. As already mentioned, the new bill introduced the crime of delinquent association of the mafia type and authorised the seizure and forfeiture of illegally acquired property of those indicted under this article. Between 1982 and 1986 nearly 15,000 men were arrested throughout Italy for criminal association of the mafia type; 706 were brought to trial by investigating magistrates in Palermo; more than half of those accused, including several mafia chiefs, received long-term or lifelong convictions (the so-called maxi-processo).

The state's renewed anti-mafia campaign won widespread public support. Shocked by the murder of Dalla Chiesa and his young wife, citizens of Palermo participated in unprecedented public demonstrations, including a spontaneous candlelight procession in honour of his memory. Since then a 'protean and multifaceted' anti-mafia movement has taken root in Italy (Schneider and Schneider, 1994). In 1985 Leoluca Orlando, a member of a reformist, left-wing current of the Christian Democratic party who had taken a clear stance against the mafia, began to serve as mayor of Palermo. During his first administration, which lasted until 1990, city hall became a focal point for attacks on the mafia. For the multiplicity of activities that accompanied Palermo's maxi-processo, the mid-1980s were labelled as 'Palermo's springtime' (see Santino, 2000; Schneider and Schneider, 2003).

After a period of retreat and disillusionment in the late 1980s, anti-mafia movements recovered energy and vitality in the early 1990s. The shocking murders, committed in rapid succession, of the magistrates Giovanni Falcone and Paolo Borsellino moved large strata of the Sicilian civil society and of the entire country. Demonstrations of an unprecedented dimension took place in Palermo as well as in other parts of Italy. A march organised in memory of Giovanni Falcone 30 days after the Capaci massacre brought an estimated 500,000 people to Palermo. 
State institutions also reacted to mafia violence with a strong counterattack, which produced the highest peak of anti-mafia activities since the fascist repression. A new anti-mafia act was passed in the summer of 1992. Seven thousand soldiers were sent to Sicily to help civil police forces, and anti-mafia investigations were beefed up. Since then, virtually all of the leading mafia bosses, some of them on the run for decades, have been captured and sent to special high-security prisons. Thanks to the creation of a Witness Protection Program, more than 1,000 mafiosi and gangsters have left their crime groups and have begun sharing their experiences with law enforcement officials (for more information on the results of the anti-mafia campaign, see La Spina's article in Part III).

Parallel to the corruption investigations of the Clean Hands Pool in Milan, several inquiries - mostly in Sicily, but to a lesser extent also in Calabria - started to reveal the extent of collusion of state representatives with Cosa Nostra and the 'Ndrangheta. Criminal proceedings were started for all the leaders of Andreotti's Sicilian supporters who had not been killed by the mafia or had not already died of natural causes. Indeed, even Andreotti, one of the most important politicians in the post-war period (he has been a member of Parliament since 1948, prime minister seven times, and a government minister countless times), was brought to trial on charges of belonging to a mafia-type delinquent association and of instigating a murder (PrPA, 1995a). In the end, however, the former Christian Democrat statesman was acquitted of both charges.

Despite the successes of anti-mafia repression, this progressively lost popular support in the second half of the 1990s. This weakening has been aided by the intrinsic limits of an anti-mafia campaign that has been exclusively entrusted to law enforcement agencies and has not been supported by a comprehensive programme to foster the social, economic, and cultural development of the South. Indeed, in the early 1990s all ad hoc measures (intervento straordinario) for the development of southern Italy came to a brusque halt. At the same time, to reduce Italy's huge public debt and to foster its entrance into the European Monetary Union, public investments were brusquely reduced (from 3.3 per cent of the GDP in 1989 to 2.1 per cent in 1995) and the whole welfare system was drastically cut, with the paradoxical result that yearly social expenses per inhabitant are today higher in northern Italy (about ITL 8.6 million, corresponding to $€ 4,500$ ) than in the south (about ITL 6.3 million, or $€ 3,300$; SVIMEZ, 1998).

It is, above all, the lasting problem of unemployment (in both Calabria and Sicily exceeding 25 per cent) that has sharply contributed to the weakening of the popular anti-mafia movement. Many of those who marched in 1992 to protest against the mafia today feel betrayed by the broken promises of national politicians, especially those belonging to left-wing parties that governed the country from 1996 to early 2001. In the political elections of May 2001, southern voters thus overwhelmingly supported the right-wing parties, most notably Silvio Berlusconi's alliance, Casa 
delle Libertà. This last, for example, won Parliament seats in all of Sicily's 60 electoral districts.

Among Berlusconi's party-men in southern Italy, there are many politicians of the old guard, but also some new ones, suspected of being linked to mafia interests. It is meaningful, for example, that Silvio Berlusconi's former right-hand man and member of the European Parliament for Forza Italia, Marcello Dell'Utri, is facing trial in Palermo on charges of being member of a mafia-type delinquent association (PrPA, 1997). In turn, in 2001 a prominent Calabrian member of Parliament of Forza Italia, Amedeo Matacena, was condemned for giving his external support [concorso esterno] to some 'Ndrangheta groups (Corriere della Sera, 14 March 2001).

Berlusconi himself has been suspected of investing and laundering Cosa Nostra's money at the beginning of his career, hiring a 'man of honour' to protect his children, regularly paying a ITL 200 million 'contribution' $(€ 100,000)$ to Cosa Nostra bosses, and colluding with the mafia in various ways. The investigation by the Palermitan Prosecutor's Office was, however, subsequently closed for the lack of any conclusive evidence (Veltri and Travaglio, 2001; Travaglio, 2001). Even if mafia defectors' statements on Berlusconi's accounts had no empirical basis, there is an objective convergence of interests between this media tycoon-turned-politician and the mafiosi. Ever since he officially entered the political game in early 1994, Berlusconi has been trying to block the anti-corruption and anti-mafia investigations that targeted him and several of his associates by staging delegitimation campaigns against law enforcement officials, calling their impartiality into question and consistently supporting legislative measures that sharpened defendants' rights and made investigations and trials more burdensome, slower, and less efficient.

Given the common interests, southern Italian mafia and other criminal groups have naturally placed their hopes of survival and recovery in Berlusconi's party. As a Calabrian pentito stated right after Berlusconi's victory at the national elections in March 1994, 'we believe that the new government will dismantle all the repressive legislation and go back to the "free state" (PrRC, 1995: 5071).

\section{Concluding Remarks}

Whereas the new Italian and foreign entrepreneurs are likely to expand their activities on Italy's illegal markets, the future of the Sicilian Cosa Nostra and the Calabrian 'Ndrangheta is more uncertain.

Far from expanding toward the outside, Cosa Nostra groups and, to a lesser extent, even those of the 'Ndrangheta have since the early 1990s receded into their territories, avoiding international competition. Today they obtain a growing and preponderant quota of their revenues by manipulating the tendering process of public works and imposing generalised extortive regimes on all the economic enterprises of their areas. Instead of creating stable 'enterprise syndicates' (Block, 
1983) capable of operating on international illegal markets, both Sicilian and Calabrian mafia families tend to fuse entrepreneurial action with the action typical of 'power syndicates' (ibid.) and thus to concentrate on those profit-making activities that are more directly advantaged by the control of a territory and collusion with politicians and government officials. The two largest mafia consortia and the once powerful camorra families have thus become ever more dependent on the decisions made by public, local, and central administrations. These administrators are today largely arbiters of both the judicial and the economic-financial lots of mafia and camorra groups.

It is, above all, to condition the outcome of the pending trials, to amend heavy first-degree sentences in appeal trials and to improve the detention conditions of the imprisoned members that the Cosa Nostra and 'Ndrangheta families need politicians and public officials to comply with them. The manipulation of state decision-making processes, however, does not merely have judicial goals, as mafia families count on their ramification in the state administration to improve their financial lot as well.

All Sicilian and Calabrian mafia families place their hopes for economic recovery in the gaining of public contracts, which have just started to be distributed once more, especially in the south, after the sharp drop following the Tangentopoli ('Bribesville', initially an allusion to Milan) inquiries. Between 2000 and 2006, Sicily and Calabria are respectively disposing of $€ 9$ billion and $€ 5$ billion coming from the European Union funds of Agenda 2000. Apparently, mafia families intend to acquire - directly and through front-men - a substantial portion of these funds and of the sums, which are being distributed by the central government and the local administrations. Unaware of being wiretapped, a Sicilian 'man of honour' recently stated: 'They say we should not make any fuss, they recommend that we all avoid making noise and attracting attention, because we have to get all this Agenda 2000 [...]' (La Repubblica, 6 February 2001: 15; see also CSM, 2001: 13-15).

What is at stake was clearly singled out in the report on the DIA's activities in the second half of 2000: 'if Cosa Nostra relies on dragging the public funds foreseen for large-scale construction works in order to recover definitively, preventing it from implementing this project could plunge it into one of the most serious crises it has ever known' (Ministero dell'Interno, 2001b: 16). Unfortunately, this awareness does seem to be shared by the cabinet headed by Silvio Berlusconi, set up in June 2001. As the Minister for Public Works, Pietro Lunardi, officially stated a few months afterwards, while talking about the huge public investments foreseen for the construction of a bridge over the Messina strait, 'in southern Italy there is the mafia and we need to come to terms with it' (La Repubblica, 23 August 2001: 2). Incompetence or mafia collusion? It is hard to say. There can be no doubt, however, about the following point: even more than in the past, mafia associations' survival now seems to depend on how their relationships with politics and different sectors of the public administration are set up in the future. 
If mafia groups do not receive the political support they desperately need, in the long-term Italy might end up having the same type of organised crime that is widespread in the rest of western Europe: namely, a myriad of criminal enterprises selling prohibited commodities with no ambitions to exercise a political power of any sort.

\section{References}

Arlacchi, P. ([1983] 1988), Mafia Business. The Mafia Ethic and the Spirit of Capitalism. Oxford, Oxford University Press.

Arlacchi, P. ([1992] 1993), Men of Dishonor. Inside the Sicilian Mafia. An Account of Antonino Calderone. New York, William Morrow.

Barbacetto, G., P. Gomez and M. Travaglio (2002), Mani Pulite. La vera storia. Rome, Editori Riuniti.

Barrese, O. (1988), I complici. Gli anni dell'antimafia. Cosenza, Rubbettino.

Becchi, A. and G. Rey. (1994), L'economia criminale. Bari-Rome, Laterza.

Becchi, A. and M. Turvani. (1993), Proibito? Il mercato mondiale della droga. Rome, Donzelli.

Bell, D. ([1953] 1988), 'Crime as an American Way of Life', in D. Bell (ed.), The End of Ideology. Cambridge, MA, Harvard University Press, 127-50.

Block, A. (1983), East Side - West Side. Organizing Crime in New York, 1930-1950. New Brunswick, NJ, Transaction Books.

Blok, A. ([1974] 1988), The Mafia of a Sicilian Village, 1860-1960. A Study of Violent Peasant Entrepreneurs. New York, Polity.

Brancato, F. (1986), La mafia nell'opinione pubblica e nelle inchieste dall'Unità d'Italia al fascismo. Studio storico elaborato per incarico della Commissione Parlamentare d'inchiesta sul fenomeno della mafia in Sicilia. Cosenza, Pellegrini.

Catanzaro, R. ([1991] 1992), Men of Respect. A Social History of the Sicilian Mafia. New York, Free Press.

Centorrino, M. (1986), L'economia mafiosa. Soveria Mannelli, Rubbettino.

Commissione P2, Commissione Parlamentare d'inchiesta sulla loggia massonica P2 (1984), Relazione di maggioranza e di minoranza, doc. XXIII, IX Legislature. Rome, Camera dei Deputati.

Commissione Sindona, Commissione Parlamentare d'inchiesta sul caso Sindona e sulle responsabilità politiche ed amministrative ad esso eventualmente connesse (1982), Relazioni di maggioranza e di minoranza, doc. XXIII, no. 2-sexies, VIII Legislature. Rome, Camera dei Deputati.

$\mathrm{CPCO}$, Commissione Parlamentare d'inchiesta sul fenomeno della criminalità organizzata mafiosa o similare (2003), Relazione annuale 2002, doc. XXIII, no. 3, XIV Legislature. Rome, Camera dei Deputati. 
CPM, Commissione Parlamentare d'inchiesta sul fenomeno della mafia e sulle altre associazioni similari (1988), Relazione sulle risultanze del gruppo di lavoro incaricato di svolgere indagini sulla criminalità organizzata e, in particolare, sul riciclaggio di proventi illeciti in provincia di Milano, doc. XXII, no. 34, X Legislature. Rome, Camera dei Deputati.

CPM, Commissione Parlamentare d'inchiesta sul fenomeno della mafia e sulle altre associazioni similari (1989), Relazione sulle risultanze dell'indagine del gruppo di lavoro della Commissione incaricato di svolgere accertamenti sullo stato della lotta alla mafia nella provincia di Reggio Calabria, doc. XXIII, no. 6, X Legislature. Rome, Camera dei Deputati.

CPM, Commissione Parlamentare d'inchiesta sul fenomeno della mafia e sulle altre associazioni similari (1992a), Audizione del collaboratore di giustizia Antonino Calderone. 11 November, XI Legislature. Rome, Camera dei Deputati.

CPM, Commissione Parlamentare d'inchiesta sul fenomeno della mafia e sulle altre associazioni similari (1992b), Audizione del collaboratore di giustizia Tommaso Buscetta. 16 November, XI Legislature. Rome, Camera dei Deputati.

CPM, Commissione Parlamentare d'inchiesta sul fenomeno della mafia e sulle altre associazioni similari (1992c), Audizione del collaboratore di giustizia Leonardo Messina. 4 December, XI Legislature. Rome, Camera dei Deputati.

CPM, Commissione Parlamentare d'inchiesta sul fenomeno della mafia e sulle altre associazioni similari (1993a), Audizione del collaboratore di giustizia Gaspare Mutolo. 9 February, XI Legislature. Rome, Camera dei Deputati.

CPM, Commissione Parlamentare d'inchiesta sul fenomeno della mafia e sulle altre associazioni similari (1993b), Relazione sui rapporti tra mafia e politica con note integrative, doc. XXIII, no. 2, XI Legislature. Rome, Camera dei Deputati.

CPM, Commissione Parlamentare d'inchiesta sul fenomeno della mafia e sulle altre associazioni similari (1993c), Relazione sulla situazione della criminalità in Calabria, con nota integrativa, doc. XXIII, no. 8, XI Legislature. Rome, Camera dei Deputati.

CPM, Commissione Parlamentare d'inchiesta sul fenomeno della mafia e sulle altre associazioni similari (1993d), Prima relazione annuale, con note integrative, doc. XXIII, no. 9, XI Legislature. Rome, Camera dei Deputati.

CPM, Commissione Parlamentare d'inchiesta sul fenomeno della mafia e sulle altre associazioni similari (1994a), Relazione su insediamenti e infiltrazioni di soggetti ed organizzazioni di mafiose in aree non tradizionali, doc. XXIII, no. 11, XI Legislature. Rome, Camera dei Deputati.

CPM, Commissione Parlamentare d'inchiesta sul fenomeno della mafia e sulle altre associazioni similari (1994b), Relazione conclusiva, doc. XXIII, no. 14, XI Legislature. Rome, Camera dei Deputati.

CPM, Commissione Parlamentare d'inchiesta sul fenomeno della mafia e sulle altre associazioni similari (2000), Relazione sullo stato della lotta alla criminalità 
organizzata in Calabria, doc. XXIII, no. 42, XIII Legislature. Rome, Camera dei Deputati.

CPM, Commissione Parlamentare d'inchiesta sul fenomeno della mafia e sulle altre associazioni similari (2001), Relazione conclusiva, doc. XXIII, no. 57, XIII Legislature. Rome, Camera dei Deputati.

CPMS, Commissione Parlamentare d'inchiesta sul fenomeno della mafia in Sicilia (1976), Relazione conclusiva, relazione sul traffico mafioso di tabacchi e stupefacenti nonché sui rapporti tra mafia e gangsterismo italo americano e relazioni di minoranza, doc. XXIII, no. 2, VI Legislature. Rome, Camera dei Deputati.

CPR, Commissione Parlamentare d'inchiesta sul ciclo dei rifiuti e sulle attività illecite ad esso connesse (1998), Relazione sulla Campania, doc. XXIII, no. 12, XIII Legislature. Rome, Camera dei Deputati.

CPR, Commissione Parlamentare d'inchiesta sul ciclo dei rifiuti e sulle attività illecite ad esso connesse (2000a), Relazione territoriale sulla regione Calabria, doc. XXIII, no. 38, XIII Legislature. Rome, Camera dei Deputati.

CPR, Commissione Parlamentare d'inchiesta sul ciclo dei rifiuti e sulle attività illecite ad esso connesse (2000b), Documento sui traffici illeciti e le ecomafie, doc. XXIII, no. 47, XIII Legislature. Rome, Camera dei Deputati.

CPR, Commissione Parlamentare d'inchiesta sul ciclo dei rifiuti e sulle attività illecite ad esso connesse (2003), Relazione alle camere sull'attività svolta, doc. XXIII, no. 9, XIII Legislature. Rome, Camera dei Deputati.

Cressey, D. (1969), Theft of the Nation. New York, Harper and Row.

CSM, Consiglio Superiore della Magistratura (2001), Verifica dell'evoluzione delle forme organizzativo-dirigenziali di Cosa Nostra al fine di un'eventuale elaborazione di proposte per attuare strategie di contrasto. Risoluzione approvata dall'Assemblea Plenaria nella seduta antimeridiana del 7 giugno 2001. Relatore: G. Natoli.

Di Lorenzo, S. (1996), La Grande Madre Mafia. Psicoanalisi del potere mafioso. Parma, Pratiche Editrice.

Di Maria, F. and G. Lavanco (1995), A un passo dall'inferno. Sentire mafioso e obbedienza criminale. Florence, Giunti.

Dino, A. (1998), 'Donne, mafia e processi di comunicazione', Rassegna Italiana di Sociologia XXXIX/4: 477-512.

Durkheim, E. ([1893, 1902, 1933] 1964), The Division of Labor in Society. New York, The Free Press.

Eco, U. ([1971] 1993), 'I Beati Paoli e l'ideologia del romanzo “popolare”'. Introduction to L. Natoli (W. Galt), I Beati Paoli. Palermo, Flaccovio.

Falcone, G. with M. Padovani ([1991] 1993), Men of Honour. The Truth about the Mafia. London, Warner.

Falcone, G. and G. Turone. (1982), 'Tecniche di indagine in materia di mafia', paper presented to the conference 'Riflessioni ed esperienze sul fenomeno mafioso' organised by the Consiglio Superiore della Magistrura. Castelgandolfo, 4-6 June. 
Organised Crime in Europe

Fentress, J. (2000), Rebels and Mafiosi. Death in a Sicilian Landscape. Ithaca, NY, Cornell University Press.

Franchetti, L. ([1876] 1993), Condizioni politiche ed amministrative della Sicilia. Rome, Donzelli.

Gambetta, D. (1993), The Sicilian Mafia. The Business of Private Protection. Cambridge, MA, Harvard University Press.

Gruppo Abele (2003), Synthetic Drugs Trafficking in Three European Cities. Major Trends and the Involvement of Organised Crime. Final Report. Turin, Gipiangrafica.

Hess, H. ([1970] 1973), Mafia and Mafiosi. The Structure of Power. Farnborough, Saxon House.

Ingroia, A. (1993), L'associazione di tipo mafioso. Milan, Giuffré.

Kaplan, D. (2003), Yakuza. Japan's Criminal Underworld. Berkeley, University of California Press.

La Duca, R. ([1971] 1993), 'Storia e leggenda de "I Beati Paoli”'. Historical and BioBibliographical Notes to L. Natoli (W. Galt), I Beati Paoli. Palermo, Flaccovio.

Legambiente. (2001), Rapporto Ecomafia 2001. L'illegalità ambientale in Itala e il ruolo della criminalità organizzata. Rome, Legambiente.

Legambiente. (2002), Rapporto Ecomafia 2002. L'illegalità ambientale in Itala e il ruolo della criminalità organizzata. Rome, Legambiente.

Lestingi, F. (1884), 'L'associazione della Fratellanza nella provincia di Girgenti', Archivio di Psichiatria, Antropologia Criminale e Scienze Penali 5: 452-63.

Lodato, S. (1999), Ho ucciso Giovanni Falcone. La confessione di Giovanni Brusca. Milan, Mondadori.

Lo Schiavo, G. (1955), 'Nel regno della mafia', Processi 5 (January): 21-5.

Lupo, S. (1988), “"Il tenebroso sodalizio.” Un rapporto sulla mafia palermitana di fine Ottocento', Studi Storici 29/2: 463-89.

Lupo, S. (1993), Storia della mafia dalle origini ai giorni nostri. Rome, Donzelli.

Marino, G. (1988), L’ideologia sicilianista. Palermo, Flaccovio.

Massari, M. (1998), La Sacra corona unita. Potere e segreto. Rome-Bari, Laterza.

Massari M. and S. Becucci (eds) (2001), Mafie nostre, mafie loro. Criminalità organizzata italiana e straniera al Centro Nord. Milan, Comunità.

Ministero dell'Interno (1994), Rapporto annuale sul fenomeno della criminalità organizzata (anno 1993), doc. XXXVIII-bis, no. 1. Rome, Camera dei Deputati.

Ministero dell'Interno (2001a), Rapporto sul fenomeno della criminalità organizzata (anno 2000). Rome, Camera dei Deputati.

Ministero dell'Interno (2001b), Relazione semestrale sull'attività svolta e i risultati conseguiti dalla Direzione Investigativa Antimafia nel secondo semestre del 2000. Rome, Ministero dell'Interno. 
Ministero dell'Interno (2001c), Relazione semestrale sull'attività svolta e i risultati conseguiti dalla Direzione Investigativa Antimafia nel primo semestre del 2001. Rome, Ministero dell'Interno.

Ministero dell'Interno (2002), Relazione semestrale sull'attività svolta e i risultati conseguiti dalla Direzione Investigativa Antimafia nel primo semestre del 2002. Rome, Ministero dell'Interno.

Ministero dei Lavori Pubblici (2000), Dati sull'abusivismo edilizio. Rome, Ministero dei Lavori Pubblici.

Monzini, P. (1999), Gruppi criminali a Napoli e a Marsiglia. La delinquenza organizzata nella storia delle due città (1820-1990). Rome, Meridiana.

Monzini, P. (2002), Il mercato delle donne. Prostituzione, tratta e sfruttamento. Rome, Donzelli.

Monzini, P., F. Pastore and G. Sciortino (2004), 'L'Italia promessa. Geopolitica e dinamiche organizzative del traffico di migranti verso l'Italia'. Working Paper no. 9, CESPI, available at <http://www.cespi.it/cnr/human_smuggling.htm>.

Mori, C. ([1932] 1993), Con la mafia ai ferri corti. Naples, Flavio Pagano.

Murray, D. (1994), The Origins of the Tiandihui. The Chinese Triads in Legend and History. Stanford, Stanford University Press.

Natoli, L. ([1908-09] 1993), I Beati Paoli. Palermo, Flaccovio.

Naylor, T. (1995), 'Loose Cannons. Cover Commerce and Underground Finance in the Modern Arms Black Market', Crime, Law and Social Change 22: 1-57.

Naylor, T. (1996), 'The Underworld of Gold', Crime, Law and Social Change 25: 191-241.

Nelken, D. (1995), 'Review of The Sicilian Mafia. The Business of Private Protection, by D. Gambetta', British Journal of Criminology 35/2: 287-9.

Paoli, L. (1997), The Pledge to Secrecy. Culture, Structure and Action of Mafia Associations. Florence, European University Institute ( $\mathrm{PhD}$ thesis).

Paoli, L. (2000), Pilot Project to Describe and Analyse Local Drug Markets. First Phase Final Report. Illegal Drug Markets in Frankfurt and Milan. Lisbon, EMCDDA.

Paoli, L. (2002), 'The Paradoxes of Organised Crime', Crime, Law and Social Change 37/1: 51-97.

Paoli, L. (2003a), 'Information on the National Legal Instruments to Control Organised Environmental Crime in Italy', in Betreuungsgesellschaft für Umweltfragen (ed.), Organised Environmental Crime in the EU Member States. A Report for the European Commission. Kassel, Betreuungsgesellschaft für Umweltfragen, 294-341.

Paoli, L. ([2000] 2003b), Mafia Brotherhoods. Organized Crime, Italian Style. New York, Oxford University Press.

Paoli, L. (2004), 'The Illegal Drugs Market', Journal of Modern Italian Studies 9/2: 188-208.

Pezzino, P. (1987), 'Stato violenza società. Nascita e sviluppo del paradigma mafioso', in M. Aymard and G. Giarrizzo (eds), La Sicilia. Turin, Einaudi, 905-84. 
Organised Crime in Europe

Pezzino, P. (1988), 'Onorata società o industria della violenza? Mafia e mafiosi tra realtà storica e paradigmi sicilianisti’, Studi Storici 29/2: 437-62.

Pezzino, P. (1990), Una certa reciprocità di favori. Mafia e modernizzazione violenta nella Sicilia postunitaria. Milan, Angeli.

Pezzino, P. (1993), 'La mafia siciliana come "industria della violenza”. Caratteri storici ed elementi di continuità', Dei Delitti e Delle Pene 2: 67-79.

Pizzorno, A. (1987), 'I mafiosi come classe media violenta', Polis 1/2: 195-204.

PrPA, Procura della Repubblica di Palermo, Direzione Distrettuale Antimafia (1992), Verbali di interrogatorio reso dal collaboratore di giustizia, Leonardo Messina. N.d.

PrPA, Procura della Repubblica di Palermo, Direzione Distrettuale Antimafia (1993), Richiesta di applicazione di misure cautelari nei confronti di Abbate Luigi +87 . 23 December.

PrPA, Procura della Repubblica di Palermo, Direzione Distrettuale Antimafia (1995a), Memoria depositata dal pubblico ministero nel procedimento penale n. 3538/94, instaurato nei confronti di Andreotti Giulio. N.d.

PrPA, Procura della Repubblica di Palermo, Direzione Distrettuale Antimafia (1995b), Memoria depositata dal pubblico ministero nel procedimento penale n. 3162/89 a carico di Greco Michele ed altri, relativa ai c.d. 'omicidi politici'(cioè agli omicidi di Michele Reina, Piersanti Mattarella, Pio La Torre e Rosario Di Salvo). N.d.

PrPA, Procura della Repubblica di Palermo, Direzione Distrettuale Antimafia (1997), Memoria depositata dal pubblico ministero nel procedimento penale $n$. 4578/96, instaurato nei confronti di Dell'Utri Marcello. March.

PrPL, Procura della Repubblica di Palmi (1993), Richiesta di rinvio a giudizio, di misure cautelari e di archiviazione nei confronti di Galluzzo Vincenzo Rosario + 81. 15 November.

PrRC, Procura della Repubblica di Reggio Calabria, Direzione Distrettuale Antimafia (1993), Domanda di autorizzazione a procedere in giudizio contro il deputato Paolo Romeo, doc. IV, no. 465, XI Legislature. Rome, Camera dei Deputati.

PrRC, Procura della Repubblica di Reggio Calabria, Direzione Distrettuale Antimafia (1995), Richiesta di ordini di custodia cautelare in carcere e di contestuale rinvio a giudizio nel procedimento contro Condello Pasquale +477 . July.

Recupero, A. (1987), 'Ceti medi e “homines novi”. Alle origini della mafia', Polis 2: 307-28.

Reuter, P. (1983), Disorganized Crime. The Economics of the Visible Hand. Cambridge, MA, MIT Press.

Rey, G. (1992), 'Analisi economica ed evidenza empirica dell'attività illegale in Italia', paper presented to Convegno della Società Italiana degli Economisti. Rome, 20 December.

Sahlins, M. (1972), Stone Age Economics. New York, Aldine Atherton.

Sales, I. (1993), La camorra. Le camorre. Rome, Editori Riuniti. 
Sales, I. (2001), 'Camorra', in Enciclopedia Treccani (ed.), Appendice 2000. Rome, Treccani, 468-69.

Santino, U. (1988), 'The Financial Mafia. The Illegal Accumulation of Wealth and the Financial-Industrial Complex', Contemporary Crises 12: 203-43.

Santino, U. and G. La Fiura (1990), L'impresa mafiosa. Dall'Italia agli Stati Uniti. Milan, Angeli.

Santino, U. (1994), La mafia come soggetto politico. Palermo, Centro Siciliano di Documentazione Giuseppe Impastato.

Santino, U. (1997), L'alleanza e il compromesso. Mafia e politica dai tempi di Lima e Andreotti ai giorni nostri. Soveria Mannelli, Rubbettino.

Santoro, M. (1998), 'Mafia, cultura e politica', Rassegna Italiana di Sociologia 39/4: $441-76$.

Santoro, M. (2000), 'Oltre lo stato, dentro la mafia. Note per l'analisi culturale di una istituzione politica', Teoria Politica 96/2: 97-117.

Scalici, E. (1885), La Cavalleria di Porta Montalto e la mafia siciliana. Naples, n.p.

Scarpinato, R. (1992), 'Mafia e politica' in Mafia. Anatomia di un regime. Rome, Librerie Associate.

Schneider, J. and P. Schneider (1976), Culture and Political Economy in Western Sicily. New York, Academic Press.

Schneider, J. and P. Schneider (1994), 'Mafia, Antimafia, and the Question of Sicilian Culture', Politics and Society 22/2: 237-58.

Schneider, J. and P. Schneider (2003), Reversible Destiny. Mafia, Antimafia and the Struggle for Palermo. Berkeley, University of California Press.

Siebert, R. (1994), Le donne, la mafia. Milan, Il Saggiatore.

Smith, M. (1974), Corporations and Society. London, Duckworth.

Stille, A. (1995), Excellent Cadavers. The Mafia and the Death of the First Italian Republic. London, Jonathan Cape.

Suchan, P. (2001), 'La criminalità organizzata cinese in Toscana', in M. Massari and S. Becucci (eds), Mafie nostre, mafie loro. Criminalità organizzata italiana e straniera al Centro Nord. Milan, Comunità.

SVIMEZ, Associazione per lo sviluppo dell'industria nel Mezzogiorno (1998), Rapporto 1998 sull'economia del Mezzogiorno. Bologna, Il Mulino.

Tranfaglia, N. (2001), La sentenza Andreotti. Politica, mafia e giustizia nell'Italia Repubblicana. Milan, Garzanti.

Travaglio, M. (ed.) (2001), 'Berlusconi e le stragi', Micromega 4: 240-54.

TrPA, Tribunale di Palermo, Ufficio Istruzione Processi Penali (1985), Ordinanza-sentenza di rinvio a giudizio nei confronti di Abbate Giovanni +706.8 November.

TrPA, Tribunale di Palermo, Ufficio Istruzione Processi Penali (1989), Verbali di interrogatorio reso dal collaboratore di giustizia, Francesco Marino Mannoia. 
Organised Crime in Europe

TrPA, Tribunale di Palermo, Ufficio del Giudice per le Indagini Preliminari (1991), Ordinanza di custodia cautelare in carcere nei confronti di Morici Serafino +4 . 9 July.

TrPA, Tribunale di Palermo, Ufficio del Giudice per le Indagini Preliminari (1993), Ordinanza di custodia cautelare in carcere nei confronti di Riina Salvatore +24 . 18 May.

TrPA, Tribunale di Palermo, Ufficio del Giudice per le Indagini Preliminari (1998), Ordinanza di custodia cautelare in carcere nei confronti di Buscemi Antonino + 9. N.d.

TrRC, Tribunale di Reggio Calabria, Ufficio del Giudice per le Indagini Preliminari (1994), Ordinanza di custodia cautelare in carcere nei confronti di Labate Pietro +17.7 January.

Turone, G. (1984), Le associazioni di tipo mafioso. Milan, Giuffrè.

Weber, M. ([1922] 1978), Economy and Society, edited by G. Roth and C. Wittich. Berkeley, University of California Press.

Vasile, V. (1994), 'Salvo Lima', in N. Tranfaglia (ed.), Cirillo, Ligato e Lima. Tre storie di mafia e politica. Bari, Laterza, 187-269.

Veltri, E. and M. Travaglio. (2001), L'odore dei soldi. Origini e misteri delle fortune di Silvio Berlusconi. Rome, Editori Riuniti. 